\title{
Onset of Lymphocyte Function in the Developing Human Fetus
}

\author{
Charles S. August, A. Izzet Berkel, Shirley Driscoll, and Ezio Merler ${ }^{[40]}$
}

Department of Pediatrics, Children's Hospital Medical Center and the Department of Pathology, Boston Hospital for Women (Lying-In Division), Harvard Medical School, Boston, Massachusetts, US.I

\section{Extract}

Lymphocytes capable of responding to phytohemagglutinin (PHA) were present in human fetal thymus tissue by 12-week gestational age and in spleens 2-4 weeks later. In spleens, establishment of the PHA response was associated with the appearance of small lymphocytes in cuffs surrounding central arterioles.

\section{Speculation}

Onset of PHA responsiveness in lymphocytes obtained from the embryonic thymus precedes that of the spleen. It would be of particular interest to know when bone marrow cells and lymph node lymphocytes start to show this function.

\section{Introduction}

The onset of immunologic function in the developing human fetus has only recently been studied systematically $[11,12,16,32]$, and existing data mainly concen immunoglobulin synthesis. What is known about the onset of cellular immune function (delayed hypersensitivity) has been largely extrapolated from animal studies [15, 23, 32]. Accumulation of human quantitative clata in this regard is essential not only for understancling the pathogenesis of many congenital infections, but also for rationalizing attempts to correct certain immunologic deficiency syndromes by the transplantation of fetal organs [15].

Studies of lymphocyte function in vitro [19], both clinically $[2,7,9,17,20]$ and experimentally $[22,28]$, suggest that it is the so-called "thymus-(lerived" lymphocyte which proliferates in vitro when exposed to phytohemagglutinin (PHA). Such cells have been identified in the thymus [16] and peripheral blood [24] of the developing human fetus at 14- and 17-week gestational age $(\mathrm{GA})$, respectively.

'The present report describes studies undertaken in
18 human fetuses of 12- to 28-week GA. Cells from thymus and spleen were cultured and the responses to PHA were estimated quantitatively. In adclition, portions of each organ were examined histologically. It was found that lymphocytes capable of responding to PHA were present in the thymus by 12-week GA and in the spleen 2-4 weeks later (14-16 weeks). In the spleen, onset of the PHA response was associated with the appearance of lymphocytes in cuffs surrounding central arterioles, the so-called "thymus-dependent" areas, as defined by Parrot, DeSousa, and East [25] and Goldschneider and McGregor [13].

\section{Materials and Methods}

\section{Preparation of Cell Suspensions}

Spleens and thymuses were obtained from noninfected fetuses which were the products of therapeutic abortions. Gestational age (from time of conception) was derived from crown-rump length measurements by referring to the data of Patten [26]. Employing sterile techniques, a small portion of each organ was placed 
in Zenker's fixing solution and submitted for histologic examination. The remainder was placed in a Petri dish in medium 199 [34] and the cells were teased into the medium with a scalpel. The debris was allowed to settle for $5 \mathrm{~min}$. The suspended cells were pipetted to achieve single cell suspension. Cells were sedimented by centrifugation at $200 \times g$ for $10 \mathrm{~min}$ and the cell pellet was resuspended in 50 times its volume of culture medium. Cells were counted in a Coulter particle counter $(100-\mu$ aperture) or with an hematocytometer and viability was estimated by the exclusion of eosin red dye [14]. Cell concentration was adjusted to $1-2 \times 10^{6}$ viable cells $/ \mathrm{ml}$. Viabilities ranged from $78-100 \%$ for thymus cells and from 21-64\% for spleen cells.

\section{Culluve Technique}

Meclium 199 with Hanks' balanced salt solution was used throughout. For washing cells, $100 \mathrm{ml}$ medium were supplemented with $2 \mathrm{ml}$ antibiotic solution containing 10,000 units penicillin G, 10,000 $\mu \mathrm{g}$ streptomycin, $50 \mu \mathrm{g}$ amphotericin $\mathrm{B}$ [35], and $\mathrm{I} \mathrm{ml}$ heat-inactivated, AB, Rh-positive, human serum. For culturing cells, $18 \mathrm{ml}$ serum were added, yielding a final serum concentration of $15 \%$.

Whenever possible, cells were cultured in duplicate in $15 \cdot \mathrm{mm}$ by $130-\mathrm{mm}$ screw top tubes of either glass or plastic. Initially, all cultures in which sufficient cells were available were carried out in 5 -ml volumes at cell concentrations of 1-2 $\times 10^{6}$ viable cells $/ \mathrm{ml}$. In later experiments, volumes were reduced to 1 or $2 \mathrm{ml}$. The $\mathrm{PH}$ [ [36] had been prepared by extracting red kidney beans (Phaseolus vulgaris) with $0.15 \mathrm{~m} \mathrm{NaCl}$. A sterile solution of this extract was added at a concentration of $0.05 \mathrm{ml} \mathrm{PHA}$ solution $/ \mathrm{ml}$ culture. Occasionally, mixed lymphocyte cultures were carried out [3]. In these instances, equal numbers of cells from each donor were used with the total cell number per tube remaining at $1-2 \times 10^{6}$ viable cells $/ \mathrm{ml}$. When sufficient cells were available, ongoing DNA synthesis at the time of culture was estimated by incubating the cells with ${ }^{3} \mathrm{H}$-thymidine for the first $16 \mathrm{hr}$ of culture. In this way, it could be determined whether PHA had actually stimu. lated or merely prolonged ongoing DNA synthesis.

All cultures to which PHA had been added, as well as untreated controls, were allowed to incubate unclisturbed for $72 \mathrm{hr}$ in an atmosphere of moist, $5 \% \mathrm{CO}_{2}$. $95 \%$ air at $37^{\circ}$. At that time, ${ }^{3} \mathrm{H}$-thymidine [37] was added to each tube to achieve a final concentration of $1.0 \mu \mathrm{Ci} / \mathrm{ml}$. The cells were returned to the inculator for $16 \mathrm{hr}$ (overnight) and harvested.

\section{Quantitation of the Proliferative Response to PHA}

Incorporation of ${ }^{3} \mathrm{H}$-thymicline into DNA was estimated by an adaptation of the filter paper disk technique of Mans and Novelli for measuring protein synthesis [21]. At the time of harvest, cells were resuspended and $0.1-\mathrm{ml}$ aliquots of the cultures were pipetted onto filter paper disks [38]. The disks were dricd and transferred to cold $10 \%$ trichloroacetic acid (TCA) containing $10 \mathrm{mg}$ unlabeled thymidine $/ 100 \mathrm{ml}$ TCA in a volume of at least $3 \mathrm{ml} /$ disk. The clisks were washed twice in 5\% TCA for $15 \mathrm{~min}$, twice in ethanol-acetone $(1: 1)$ at $37^{\circ}$ for at least $30 \mathrm{~min}$, and twice in acetone for $15 \mathrm{~min}$. The disks were placed in vials and the radioactivity was estimated in a liquid scintillation spectrometer. Results were expressed as $\mathrm{cpm} / 10^{5}$ viable cells originally cultured. No corrections for the absorption of radioactivity to the disks were made. The average variation from the mean in cultures stimulated by PHA was $5.8 \%$ (range $0.4-11 \%$ ). The average variation of unstimulated controls was $12.4 \%$ (range $0-38 \%$ ). A "stimulation inclex" (SI) was calculated as the ratio of $\mathrm{cpm} / 10^{5}$ cells in the stimulated culture to that in the control.

\section{Histologic Examination}

All specimens were coded and examined without prior knowledge of the results of PHA stimulation. Thymuses were evaluated by two main criteria: (1) the demarcation into lymphoid cortex and medulla, and (2) the presence of Hassall's corpuscles. In the spleens, evidence was sought for the differentiation into red and white pulp by the presence of $(1)$ arterioles, (2) small lymphocytes surrounding arterioles (cuffs) and (3) germinal centers. When histologic examination was complete, the results were correlated, both with gestational age and the results of PHA stimulation.

\section{Results}

\section{Corrclation of PHA Responses with Histologic Ap. pearance}

Thymus glands and spleens from 18 fetuses of 12- to 28-week GA were studied. The clata from 16 technically satisfactory experiments using thymus cells and 15 using spleen cells are shown in Table I, together with a summary of the histologic appearance of each organ. Thymus cells responded to PHA by increased incorporation of ${ }^{3} \mathrm{H}$-thymicline into DNA whenever they were tested, that is, from 12-week GA onward. Histologic examination revealed that all thymuses had 
Table 1 . Correlation of PHA responsiveness, histologic appearance, and gestational age in 18 human fetal thymuses and splecns

\begin{tabular}{|c|c|c|c|c|c|c|c|c|c|c|c|c|c|}
\hline \multirow{3}{*}{$\begin{array}{l}\text { Speci- } \\
\text { men }\end{array}$} & \multirow{3}{*}{$\begin{array}{l}\text { Crown- } \\
\text { rump } \\
\text { length, } \\
\text { cm }\end{array}$} & \multirow{3}{*}{$\begin{array}{c}\text { Estimated } \\
\text { gesta- } \\
\text { tional } \\
\text { age, } \\
\text { weeks }\end{array}$} & \multicolumn{5}{|c|}{ Thymus } & \multicolumn{5}{|c|}{ Spleen } & \multirow{3}{*}{$\begin{array}{c}\text { SI } \\
\text { thymus/ } \\
\text { SI spleen }\end{array}$} \\
\hline & & & PHA & Control & $\mathrm{SI}^{1}$ & \multicolumn{2}{|c|}{ Histology } & PHA & Control & $\mathrm{SI}^{1}$ & \multicolumn{2}{|c|}{ Histology } & \\
\hline & & & & $\mathrm{m} / 10^{t}$ cells & & $\mathrm{LC}^{2}$ & $\mathrm{HC}^{2}$ & & $10^{8}$ cells & & $\mathrm{CA}^{4}$ & $\mathrm{LC}^{\mathrm{s}}$ & \\
\hline 1 & $7.5-8$ & 12 & & & & + & 0 & & & & 0 & 0 & \\
\hline 2 & 8.0 & 12 & & & & + & 0 & & & & 0 & 0 & \\
\hline 3 & 8.0 & 12 & 1,180 & 93 & 13 & & & 78 & 73 & 1 & & & 13 \\
\hline 4 & 8.0 & 12 & 24,274 & 873 & 28 & & & 881 & 321 & 3 & 0 & 0 & 9 \\
\hline 5 & 8.2 & 12 & 2,641 & 377 & 7 & + & 0 & 452 & 574 & 0.8 & 0 & 0 & 9 \\
\hline 6 & 8.5 & 12.5 & 16,399 & 727 & 23 & + & & 1,568 & 527 & 3 & + & \pm & 8 \\
\hline 7 & 10.0 & 13.5 & 4,203 & 126 & 33 & + & + & 617 & 239 & 3 & + & 0 & 11 \\
\hline 8 & 10.7 & 14 & 7,817 & 213 & 37 & + & + & 2,832 & 1,019 & 3 & \pm & 0 & 12 \\
\hline 9 & 11.0 & 14 & 5,337 & 57 & 94 & + & 0 & 9,154 & 904 & 11 & \pm & 0 & 9 \\
\hline 10 & 11.0 & 14.2 & 4,388 & 202 & 22 & + & + & 1,820 & 1,067 & 2 & \pm & 0 & 11 \\
\hline 11 & 11.5 & 14.5 & 1,889 & 159 & 12 & + & \pm & 14 & 5 & & \pm & 0 & \\
\hline 12 & 11.5 & 14.5 & 2,750 & 61 & 45 & + & \pm & 401 & 31 & 13 & \pm & $0- \pm$ & 3 \\
\hline 13 & 12.0 & 15 & 16,621 & 321 & 52 & + & + & \multicolumn{2}{|c|}{ Contaminated } & & + & 0 & \\
\hline 14 & 12.5 & 15.5 & 1,885 & 18 & 106 & + & \pm & 611 & 57 & 11 & + & \pm & 10 \\
\hline 15 & 14.0 & 16.5 & 11,688 & 762 & 15 & + & + & 12,416 & 1,402 & 9 & + & \pm-+ & 2 \\
\hline 16 & 15.3 & 17.5 & 2,872 & 46 & 63 & + & + & 4,048 & 91 & 45 & + & \pm & 1 \\
\hline 17 & 15.5 & 17.5 & 2,045 & 88 & 23 & + & + & 5,780 & 600 & 10 & + & + & 2 \\
\hline 18 & 36 & 28 & 3,442 & 182 & 21 & + & 0 & 7,042 & 360 & 20 & + & + & I \\
\hline
\end{tabular}

1 SI : Stimulation index; all numbers and ratios have been rounded off to the nearest whole number.

${ }^{2}$ LC: Lymphoid ccrtex.

${ }^{3} \mathrm{HC}$ : Hassall's corpuscles.

${ }^{4} \mathrm{C} A$ : Central arterioles.

${ }^{5}$ Lymph cuffs.

demarcated into a lymphoid cortex and medulla (Figs. 1 and 2). Hassall's corpuscles were found regularly beginning at 14.5-week GA. The absence of Hassall's corpuscles in the 28-week GA thymus was thought to be clue to an artifact of section.

In contrast to the development in the thymus gland, the earliest spleen cells which responded to PHA with an SI greater than 3 were obtained from a fetus of 14-week GA. Indeed, the cells from only two of 11 spleens cultured prior to 16-week GA incorporated more than $4000 \mathrm{cpm} / 10$ " cells. Histologic examination of the spleens revealed that the specimens obtained at 12-week GA were almost entirely red pulp with only scattered mononuclear cells (Fig. 3). Between 12- and 15-week GA, central arterioles began to appear which, at first, lacked the cuff of small lymphocytes which is characteristic of a mature organ (Fig. 4). In the next few weeks, more mononuclear cells appeared, at first scattered about the red pulp and then in cuffs only a few cells deep surrounding central arterioles. Touch preparations from these specimens showed the presence of many erythrocyte precursors. As early as 17 . week GA, and particularly in the 28-week GA spleen, almost all central arterioles were surrounded by prominent cuffs of mononuclear cells easily identified as small lymphocytes (Fig. 5). By that time, the proliferative response of spleen cells to PHA was well established. No germinal centers were found in any of the spleens examined.

The relation between the stimulation index (SI) calculated from the data in Table I and the gestational age is shown in Figure 6. Although the variation of the SI in cultures which responded was considerable, it was clear that PHA responsiveness of spleen cells lagged behind that of thymus cells by $2-4$ weeks.

\section{Intrinsic Rate of DNA Synthesis and PHA Stimulation}

Cells derived from fetal thymuses were mixtures of medium and small lymphocytes, as well as of more primitive cells. It might be predicted and has been shown biochemically [6] that at least some of these cells actively synthesize DNA at the outset of culture. It was of interest to determine whether PHA had stimulated or simply prolonged ongoing DNA synthesis. In an experiment carried out for $27 \mathrm{hr}$, it was found that ${ }^{3} \mathrm{H}$-thymidine was incorporated into DNA linearly for $8 \mathrm{hr}$, after which time no new šnththesis occurred. In the four thymuses and two spleens in which sufficient cells were available, DNA synthesis during the first 16 hr in vitro was compared with that observed after 72 


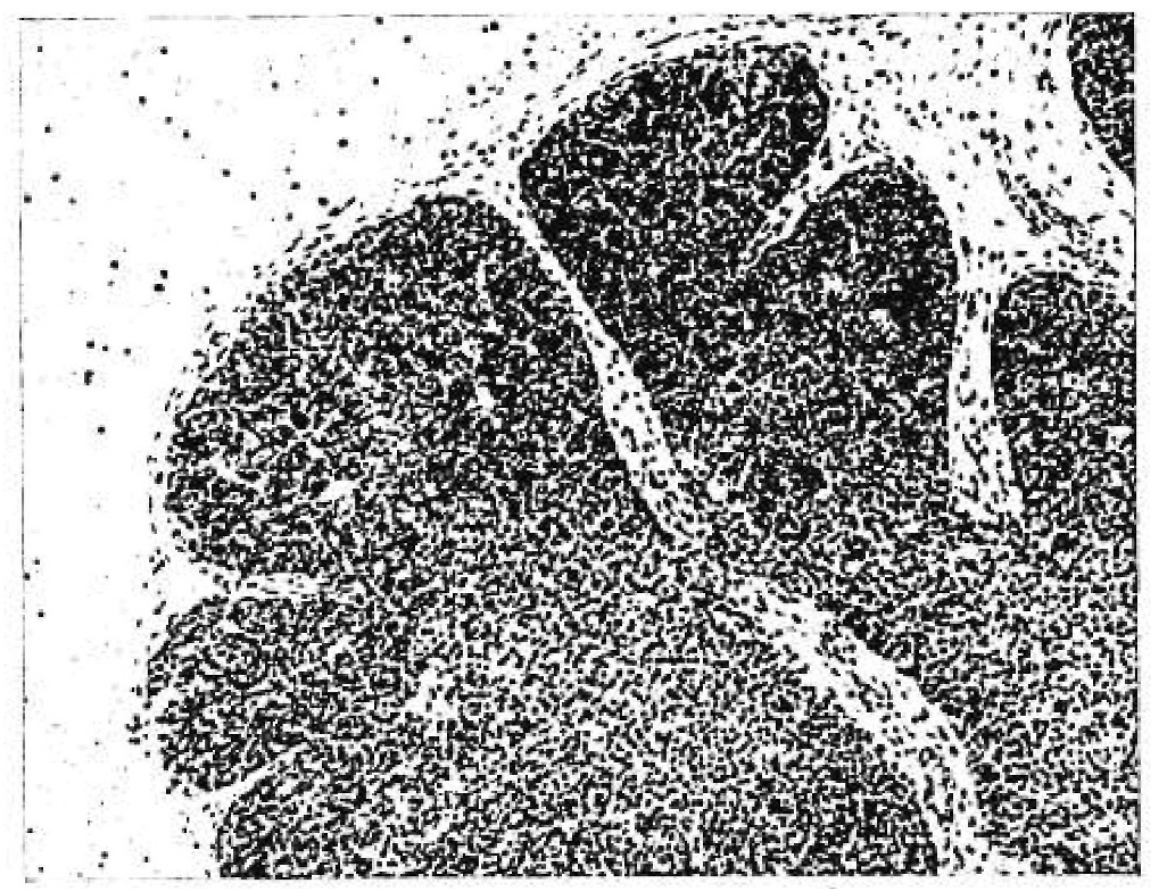

Fig. 1. Thymus from a human fetus of 11 -weeks $\mathrm{G} \Lambda$. Note the demarcation into lymphoid cortex and medulla. No Hassall's corpuscles are present. Toluidene blue and eosin. $\times 80$.

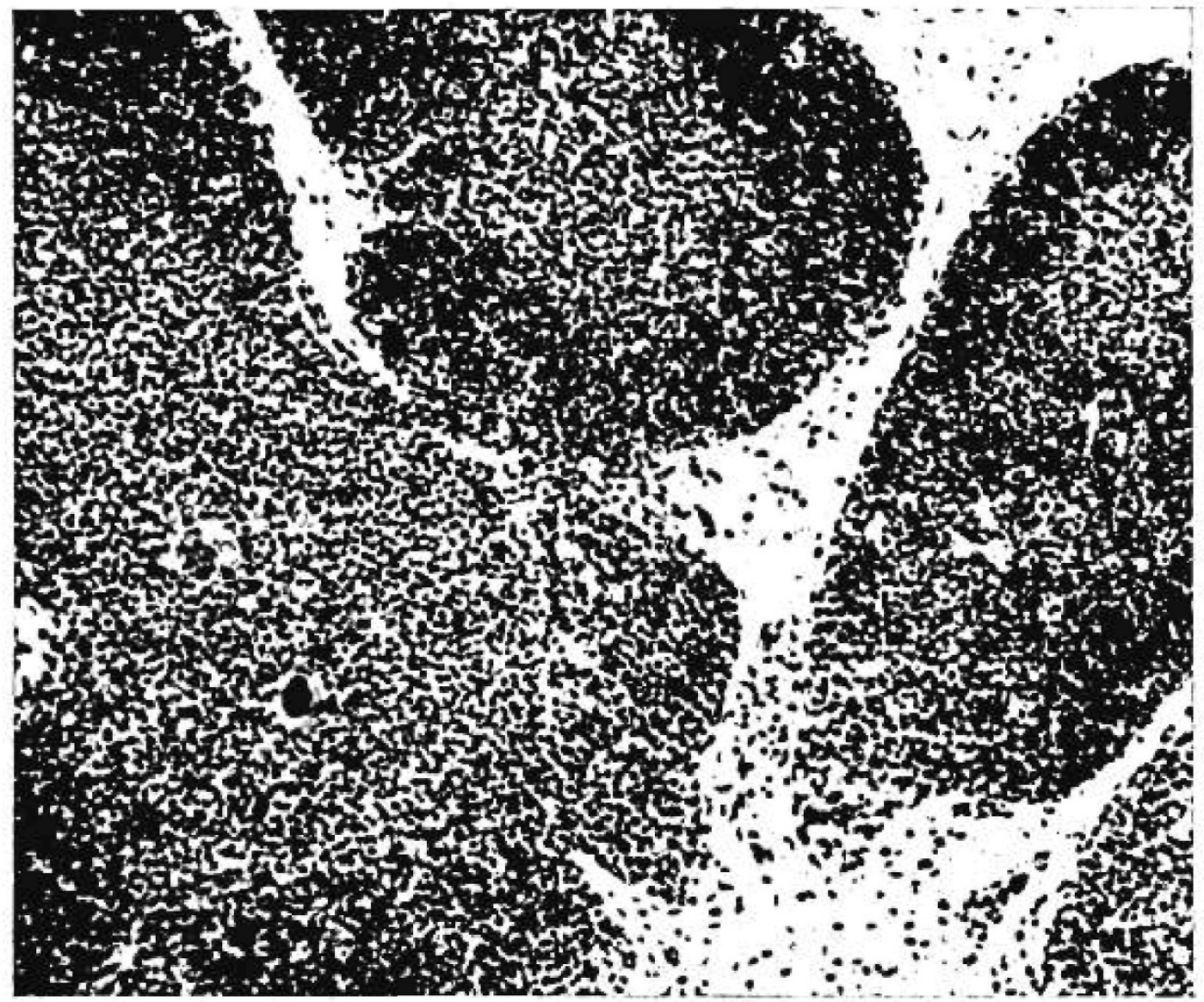

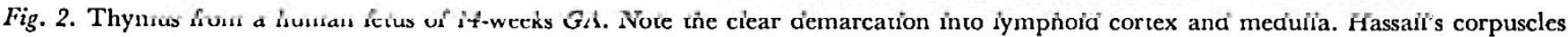
are present. Toluidine blue and eosin. $\times 32$. 


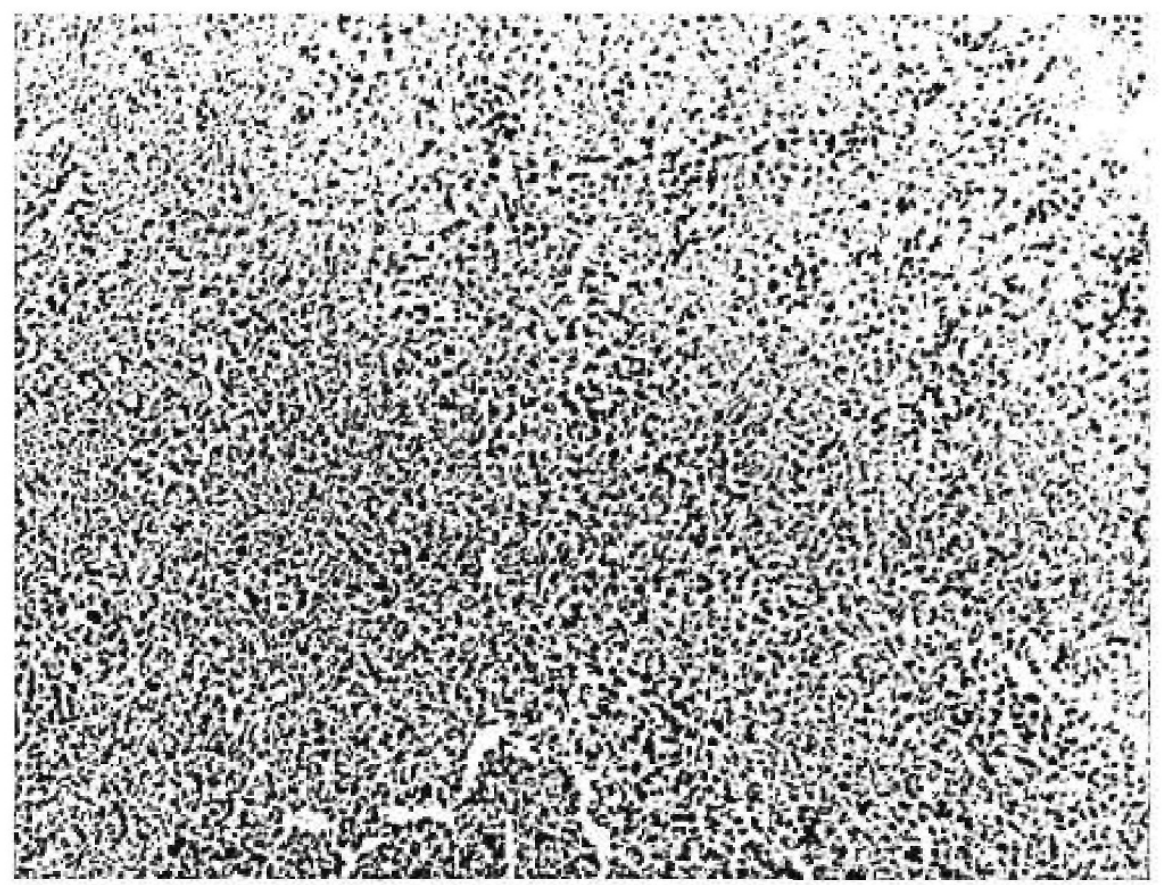

Fig. 3. Spleen from a human fetus of 11 -weeks GA. Only scattered mononuclear cells are present. Toluidine blue and eosin. $\times 80$.

hr in PHA-stimulated and control cultures. Table II indicates that in five of six cultures the magnitude of the PHA response during the 4th day exceeded the initial level of DNA synthesis by 200-1200\%. Similarly, in five of six unstimulated controls, DNA synthesis declined from $3-21 \%$ of the initial value.

\section{Responses of Fetal Lymphocyles to Allogeneic Cells}

Mixed leukocyte cultures between fetal cells and aclult peripheral blood leukocytes of the opposite sex or treated with mitomycin $\mathrm{C}$ were technically unsatisfactory. Specimens 13 and 15 became available simultaneously, and it was possible, therefore, to mix thymic cells from two fetuses of 15- and 16.5-week GA. Table III presents the results of this experiment, which clearly show that there had been vigorous proliferation in the mixture of allogeneic cells.

\section{Discussion}

This study of fetal thymus glands and spleens inclicates that in man from at least the 12th gestational week onward the thymus has differentiated into functional lymphoid cortex and medulla. Starting at 12-week GA, fetal thymocytes were capable of responding to PHA by increasing DNA synthesis. In contrast, spleens of 12 to 13-week GA contained no recognizable lymphoid tissue and the cells teased from these organs responded feebly to PHA. PHA responsiveness began in spleen cells at about 14-week GA and was fully established only after 16-week GA. These data correlated well with the appearance of scattered groups of lymphocytes in 14 . weak-old fetal spicen samples and with the appearance of larger numbers of lymphocytes found cuffing the central arterioles after 16-week GA. The morphologic data presented, indicating peripheral localization of lymphoid cells from thymus to spleen in the developing embryo, were identical with that clescribed in a number of animal species [23], particularly rabbits [1] and opossums [4].

This study also includes some preliminary data which suggest that the ability of fetal thymus cells to proliferate in response to allogeneic stimuli is present around 15- to 16.5-week GA. This is consistent with the observations of Siegler and Metzgar [30], who found that at this time in fetal life the thymus is alreacly enclowed with histocompatibility (HL-A) antigens.

Our findings supplement earlier work concerning human maturation, the purpose of which was usually to obtain mitoses suitable for cytogenetic analyses. This work, summarized by Ling [19] and van Furth [10], suggested from morpho'ogic studies that thymic lymphocytes at 14-week GA and spleen cells at 19- to 20-week GA responded to PHA. Recently, Papiernik 


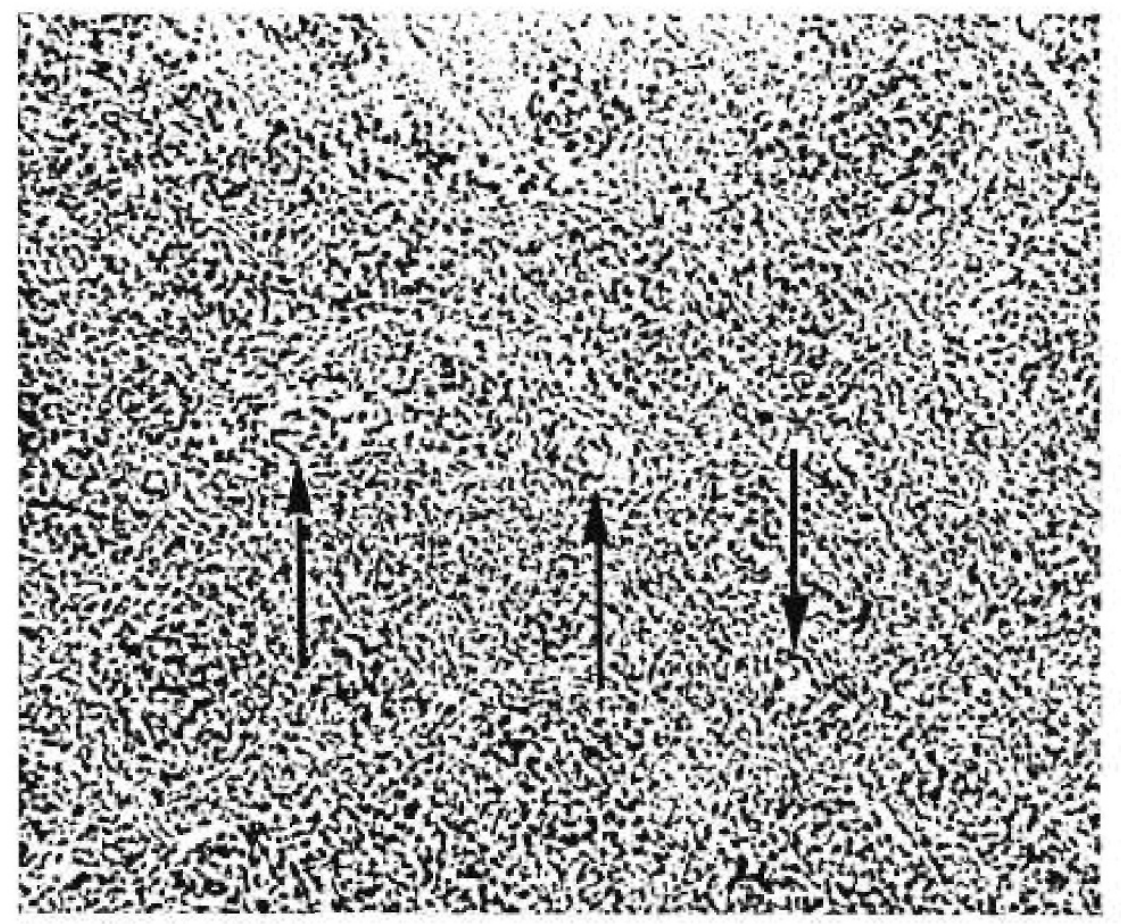

Fig. 4. Spleen from a human fetus of 14-week GA. Arterioles (arrows) are present but lack cuffs of small lymphocytes. Mononuclear cells are more numerous than at 11 wecks but still appear disorganized. Toluidine blue and eosin. $\times 80$.

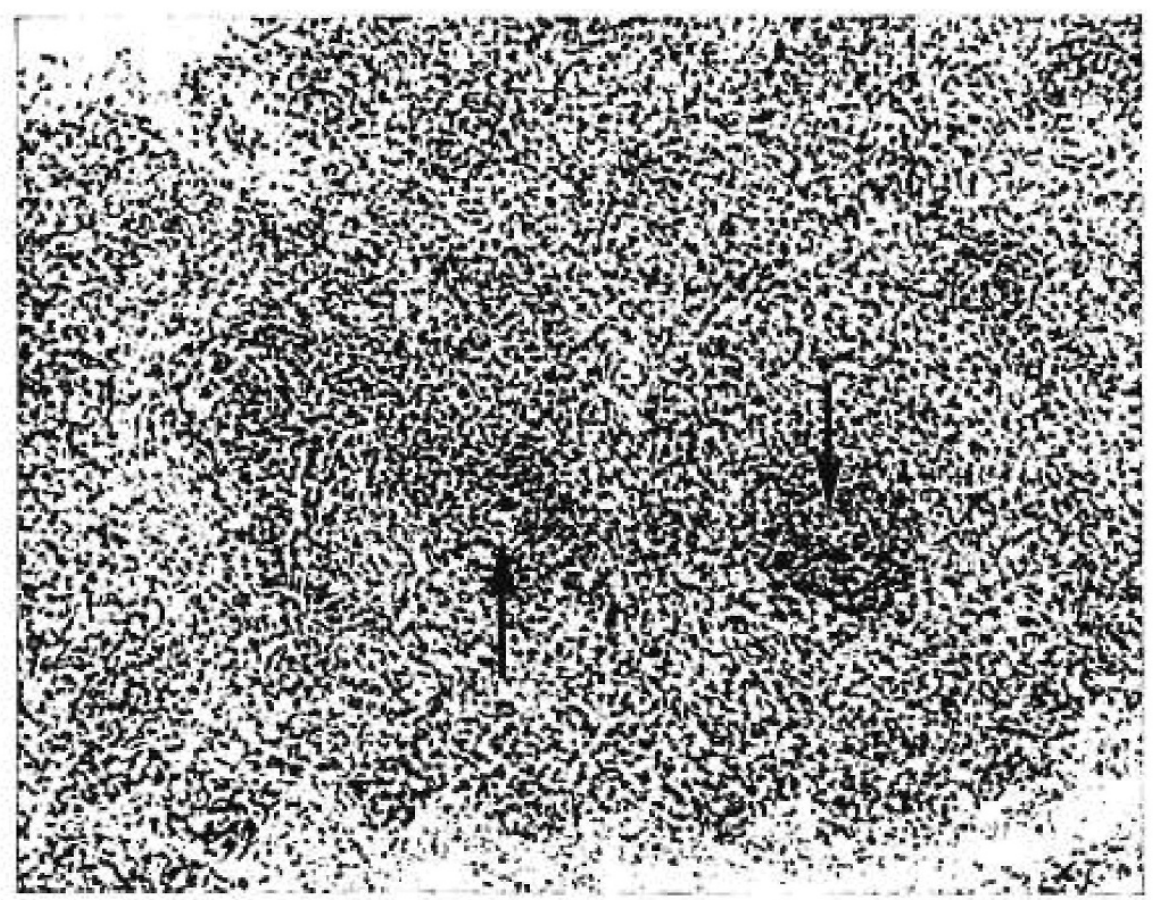

Fig. 5. Spleen from a human fetus of 28 -week GA. Note the prominent cuffs of small lymphocytes surrounding central arterioles (arrows). No germinal centers are present. Toluidine blue and eosin. $\times 80$. 
[24] using autoradiography found that cells from thymus glands and peripheral blood from fetuses between 17- and 22-week GA proliferated in response to PHA. More recently, Kay, Doe, and Hockley [16] dated the onset of PHA responsiveness in human thymocytes at about 14-week GA. The quantitative methods employed in the present study and comparisons of the initial level of DNA synthesis with the values seen in stimulated and control cultures 3 days later appear to overcome the difficulty described by Kay [15] in quantitating "a system where only a few cells respond and where control cultures ... always contain some blastlike cells." Our data indicate that PHA stimulated DNA synthesis above and beyond the level which existed at the beginning of culture.

The immunologic significance of the capacity of lymphocytes to respond to PHA has recently been clarified. It has been shown in experimental animals that neonatal thymectomy, which impairs cellular immune function, also diminishes the ability of animal lymphocytes to respond in vitro to this mitogen $[22,28]$. The lymphocytes of patients with congenital absence of the thymus are unable to proliferate normally in response to PHA $[7,9,15,20]$. Correcting the immunologic deficiency in such patients by implanting fetal thymus tissue, however, has also restored the ability of lymphocytes to respond to PHA [2, 7]. Thus, it appears that normal lymphocyte response to PHA requires an intact population of peripheral lymphocytes which have been influenced by the thymus, and in vitro testing therefore appears to constitute a means of identifying this lymphocyte population.

It cannot be determined from the present study whether the PHA-responsive lymphocytes found in thymuses and spleens early in gestation are, in fact, immunologically competent. The results of the mixed leukocyte culture suggest that fetal thymocytes can proliferate in response to an allogeneic stimulus. Whether these cells can synthesize the mediators of cellular immune reactions [8] is unknown. Gitlin and Biascusi, however [12], have reported that cells obtained from fetal thymuses of 17- to 18-week GA were able to synthesize IgM and IgG. The results of our lymphocyte function studies correlate well with the studies of Silverstein and Kraner [31], who observed allograft rejections in fetal monkeys approximately one-third of the way through gestation. Our correlations of lymphocyte function with histologic appearance are reminiscent of the studies of Rowlands, LaVia, and Block [29], who found that antibody synthesis began in opossum embryos immediately after

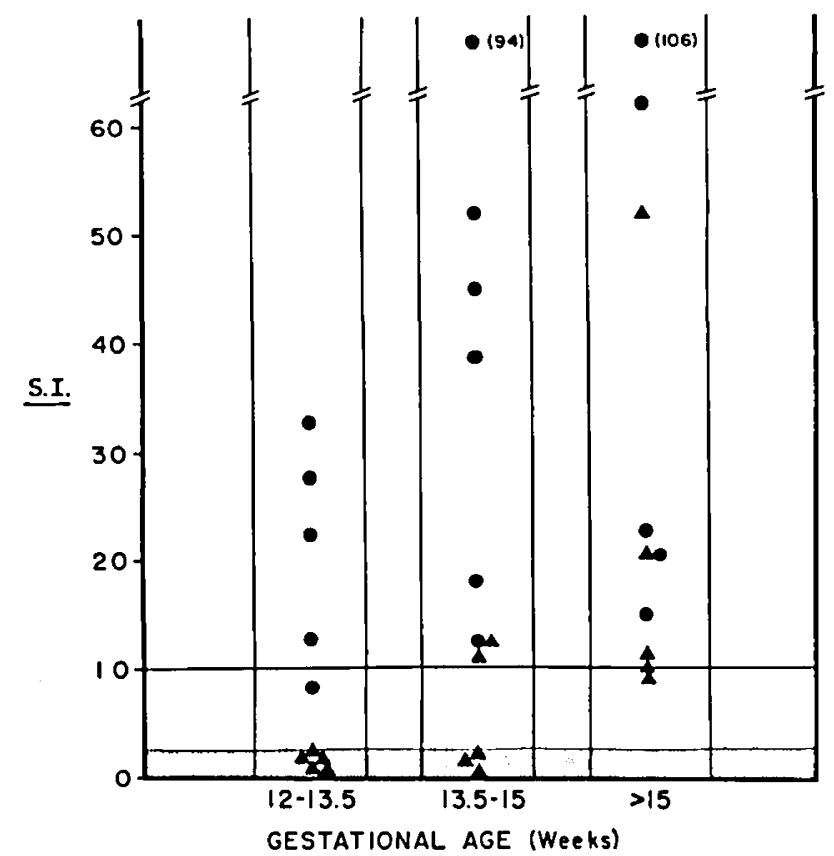

Fig. 6. Responses to PHA of human fetal thymocytes (•) and spleen cells $(\boldsymbol{\Delta})$ of varying gestational ages. The stimulation index (SI) is calculated as in the text: SI of 0 to 3 (hatched area) represents little or no response; SI of 3 to 10 represents poor to fair response; SI greater than 10 represents the normal range for adult peripheral blood lymphocytes.

Table II. The DNA synthesis by fetal lymphoid cells on the 1st day of culture compared with PHA-stimulated DNA synthesis after 4 days

\begin{tabular}{|c|c|c|c|c|c|c|}
\hline \multirow{4}{*}{ Specimen } & \multirow{4}{*}{ Organ } & \multirow{3}{*}{$\frac{\text { Day } 1}{\begin{array}{c}\text { Unstim- } \\
\text { ulated }\end{array}}$} & \multicolumn{2}{|c|}{ Day 4} & \multirow{2}{*}{\multicolumn{2}{|c|}{$\begin{array}{l}\text { Ratio of day } \\
4 \text { to day } 1\end{array}$}} \\
\hline & & & \multirow{2}{*}{ PHA } & \multirow{3}{*}{$\begin{array}{l}\text { Unstim- } \\
\text { ulated }\end{array}$} & & \\
\hline & & & & & \multirow{2}{*}{ PHA } & \multirow{2}{*}{$\begin{array}{l}\text { Unstim } \\
\text { ulated }\end{array}$} \\
\hline & & & $n / 10^{5} c$ & & & \\
\hline 12 & Thymus & 564 & 2750 & 61 & 4.9 & 0.10 \\
\hline 14 & Thymus & 634 & 1885 & 18 & 3.0 & 0.03 \\
\hline 14 & Splecn & 267 & 611 & 57 & 2.3 & 0.21 \\
\hline 16 & Thymus & 665 & 2872 & 46 & 4.3 & 0.07 \\
\hline 17 & Thymus & 2357 & 2045 & 88 & 0.9 & 0.04 \\
\hline 17 & Splecn & 475 & 5780 & 600 & 12.2 & 1.30 \\
\hline Average & & & & & 4.6 & 0.29 \\
\hline
\end{tabular}

Table III. Mixed lymphocyte response of fetal thymuses

\begin{tabular}{|c|c|c|c|}
\hline \multirow{2}{*}{ Specimen } & \multirow{2}{*}{$\begin{array}{l}\text { Gestational } \\
\text { age, weeks }\end{array}$} & Control & $M i_{x}$ \\
\hline & & \multicolumn{2}{|c|}{$\mathrm{cpm} / 10^{6}$ cells } \\
\hline 13 & 15 & 321 & \\
\hline 15 & 16.5 & 762 & 5925 \\
\hline
\end{tabular}

the appearance of lymphoid tissue in the thymus and a few lymph nodes.

The changing listologic appearance of the spleen suggests that the onset of thymus-derived lymphocyte 
function in that organ occurred during the period encompassed by the present study. Studies in experimental animals $[13,25,27,33]$ have established that thymus-derived lymphocytes migrate out of the blood stream within the spleen and localize in sheaths surrounding central arterioles. These areas have been designated "thymus-dependent" [25]. The present data suggest that in the spleen the onset of PHA responsiveness accompanies the population of thymus-dependent regions during the 14 th to the 16 th week of gestation. It is noteworthy that no spleen showed germinal centers. These are thought to arise only after antigenic stimulation and to be related to immunoglobulin production rather than cellular immunity [5].

It is pertinent to note that LaVia et al. [18], using opossums as the animal model, found that antibody synthesis could not be detected when the thymus was the sole lymphoid organ. They concluded that some peripheral localization of lymphoid cells from the thymus was required for antibody synthesis. If this reasoning can be extrapolated to man, then on the basis of our data the onset of immunologic competence might be expected between the 12th and 16 th week of gestation.

\section{Summary}

The onset of lymphocyte function in the developing human fetus was studied by culturing in vitro lymphoid cells obtained from spleens and thymus glands of 16 fetuses of 12- to 28-weck gestational age (GA). The response of these cells to phytohemagglutinin (PHA) was determined by measuring the incorporation of ${ }^{3} \mathrm{H}$ thymidine into deoxyribonucleic acid. In addition, cach organ was examined histologically. It was found that PHA-responsive lymphocytes were present in the thymus at 12-wcek GA and in the spleen 2-4 weeks later (14- to 16-week GA). All thymuses examined had demarcated into lymphoid cortex and medulla. In the spleens, the onset of PHA response correlated with the alppearance of small lymphocytes.

\section{References and Notes}

1. Archer, O. K., Paipermastek, I3. W., and Good, R. A.: Thymectomy in rabbit and mousc: consicleration of time of lymph. oid peripheralization. In: R. $\Lambda$. Good and A. E. Gabriclson: The Thymus in Immunobiology, pp. 414-431 (Hoeber, New York, 1964).

2. August, C., Rosen, F. S., Filler, R. W., Janeivay, C. A., MARKowski, B., AND KAY, II. E. M.: Implantation of a foetal thymus restoring immunological competence in a patient with thymic aplasia (1)iGcorge's syndrome). Lancet, $i i$ : 1210 (1968),
3. BAC1, F. H., ANo Voynow, N. K.: One-way stimulation in mixed leukocyte cultures. Science, 153: 545 (1966).

4. BLOCK, M.: The blood-forming tissues and blood of the newborn opossum (Didelphy's virginiana). I. Normal development through about the one-hundredth day of life. Ergeb. Anat. Entwgesch., 37: 237 (1964).

5. Bridges, R. A., Condie, R. M., ZAK, S. J., ANd Good, R. A.: The morphologic basis of antibody formation development during the neonatal period. J. Lab. Clin. Med., 53: 331 (1959).

6. Claman, H. N., and Brunstetrer, F. H.: Effects of antilymphocyte serum and phytohemagglutinin upon cultures of human thymus and peripheral blood lymphoid cells. I. Morphologic and biochemical studies of thymus and blood lymphoid cells. Lab. Invest., 18: 757 (1968).

7. Cleveland, W. W., Fogel, B. J., Bkown, W. T., and Kay, II. E. M.: Foetal thymic transplant in a case of DiGeorge's syndrome. Lancet, ii: 1211 (1968).

8. DAvid, J.: Delayed hypersensitivity. In: P. Miescher and $\mathbf{H}$. Mfuller-Eberhard: Immunopathology, pp. 111-131 (Grunc and Stratton, Inc., New York, 1967).

9. DiGeorge, A. M.: Congenital absence of the thymus and its immunologic consequences: concurrence with congenital hy. poparathyroidism. In: D. Bergsma: Immunologic Deficiency Diseases in Man, Vol. 1, pp. 110-121 (National Foundation, New York, 1968).

10. van FurTh, R.: Formation of immunoglobulins by circulating lymphocytes. Seminars Hematol, 6: 84 (1969).

11. van FurTh, R. Schutr, H. R. E., and Hijnans, W.: The immunological development of the human fetus. J. Exp. Med., 122: 1173 (1965).

12. Githlin, D., AND Busucci, A.: Development of $\gamma \mathrm{G}, \gamma \mathrm{A}, \gamma \mathrm{MI}$, $\beta_{1} \mathrm{C} / \beta_{1} \Lambda, C^{\prime}$-1-esterase inhibitor, ceruloplasmin, transferrin, hemopexin, haptoglobin, fibrinogen, plasminogen, $\alpha$-1-antitrypsin, orosomucoid, $\beta$-lipoprotein, $\alpha$-2-macroglobulin, and prealbumin in the human conceptus. J. Clin. Invest., f8: 1433 (1969).

13. Goldschineider, I., AND MCGregor, D. D.: Migation of lym. phocytes and thymocytes in the rat. I. The route of migration from blood to spleen and lymph nodes. J. Exp. Med., 127: 155 (1968).

14. HaNks, J. H., AND WALLACE, J. II.: Determination of cell viability. Proc. Soc. Exp. Biol., $9 S$ : 188 (1958).

15. KAY, H. E. M.: Concepts of cellular deficiency and replacement therapy in immune deficiency. In: D. Bergsma: Immunologic Deficiency Diseases in Man, Vol. II, pp. 168-172 (National Foundation, New York, 1968).

16. KAY, H. E. M., DoE, J., AND HockLEY, A.: Response of human foetal thymocytes to phytohaemagglutinin (PHA). Immunology, 18: 393 (1970).

17. Kretscinmer, R., SAy, B., Brown, D., and Rosen, F. S.: Congenital aplasia of the thymus gland (DiGcorge's syndrome). New Engl. J. Med., 279: 1295 (1968).

18. LaVis, M. F., Rowlands, D. T., JR., and Block, M.: Antibody formation in embryos. Science, 140: 1219 (1963).

19. Ling, N. R.: Lymphocyte Stimulation. (John Wiley and Sons, Inc., New York, 1968).

20. Lischner, H. W., Punnett, H. II., and DiGeorge, A. M.: Lymphocytes in congenital absence of the thymus. Nature, $214: 580$ (1967).

21. MAns, R. J., AND Novelli, G. D.: Measurement of the incorporation of radioactive amino acids into protein by a fil- 
ter paper disk method. Arch. Biochem. Biophys., 94: 48 (1961).

29. Meuwissen, H. J., Van Alten, P. J., Bach, F. H., And Good, R. A.: Influence of thymus and bursa on in vitro lymphocyte function. In: D. Bergsma: Immunologic Deficiency Diseases in Man, Vol. I, pp. 253-256 (National Foundation, New York, $1968)$.

23. Mil...R, J. F. A. P.: Immunity in the foctus and the newborn. Brit. Med. Bull., 22: 21 (1966).

24. Pairifnik, M.: La maturation des lymphocytes thymiques et sanguins foetaux humains. Etude de la transformation blastique. Pathol, Eur., t: 75 (1969).

25. Parrott, D. V., DeSousa, M. A., and East, J.: Thymusdependent areas in lymphoid organs of neonatally thymectomized mice. J. Exp. Med., 123: 191 (1966).

26. PAtren, B.: Human Embryology, p. 185 (McGraw-Hill, New York, 1957).

27. Pritersen, J. C., And Rose, R. J.: Marginal zone and germinal center development in the spleens of neonatally thymectomized and nonthymectomized young rats. Amer. J. Anat., 123: 489 (1968).

28. Rieke, W. O.: Lymphocytes from thymectomized rats: immunologic, proliferative, and metabolic properties. Science, 152: 535 (1966).

29. Rowlands, D. T., Jr., LaVia, M. F., and Block, M.: The blood-forming tissuc and blood of the newborn opossum (Didelphys virginiana). II. Ontogencsis of antibody formation of flagella of Salmonella typhi. J. Immunol., 93: 157 (1964).

30. Siegler, H. F., AND MetzGar, R. S.: Embryonic devclopment of human transplantation antigens. Transplantation, 9: 478 $(1970)$.

31. Silverstein, A. M., AND Kranek, K. L.: Studies on the ontogenesis of the immune response. In: J. Sterzl: Molecular and Cellular Basis of Antibody Formation, pp. 341-348 (Academic Press, New York, 1965).

32. Sterze, J., ANd Silverstein, A. M.: Developmental aspects of immunity. Advan. Immunol., 6: 337 (1967).

33. Weissman, I. L.: Thymus cell migration. J. Exp. MIcd., 126: 291 (1967).

34. Microbiological Associates, Bethesda, Mod.

35. Grand Island Biological Company, Long Island, N. Y.

36. A gift of Dr. Park S. Gerald, Children's Hospital Medical Center, Boston, Mass.

37. New England Nuclear Corporation, Boston, Mass., specific activity, $2.0 \mathrm{Ci} / \mathrm{mmole}$.

38. Whatman no. $3,2.3 \cdot \mathrm{cm}$ diameter.

39. Supported by Public Health Service Research Grant no. AI05877. Dr. August was the recipient of Special Postdoctoral Fellowship no. AM-35561 from the National Institute of Arthritis and Metabolic Diseases. Present address: Department of Pediatrics, University of Colorado School of Medicine, 4200 East Ninth Avenuc, Denver, Colo. 80220 (USA). Dr. Berkel was a Fulbright Scholar supported in part by United States Department of State Grant no. 69 101-A.

40. Requests for reprints should be addressed to: Ezio MerLer, Immunology, Children's Hospital Medical Center, 300 Long. wood Avenuc, Boston, Mass. 02115 (USA).

41. Accepted for publication December 4, 1970. 